in the graduate curriculum. Materials are related to each other in terms of narrow specialization. To what extent does the organization of materials in libraries facilitate an understanding of the social results of technological process on the part of the graduate science student? 'To what extent does the organization promote the formulation of a philosophy of purpose on the part of the graduate social science student? To what extent does it aid the graduate library student in integrating subject content with the techniques of his profession? The shortcomings of library organization are apparent enough under the present system. They may reach the breaking point if additional educational demands are made upon the library.

There is also a connection between $\mathrm{Mr}$. Hollis' thesis and graduate education for librarianship. In the past all professional fields have come in for a full measure of censure as legitimate areas for graduate academic study from such critics as Abraham Flexner and Norman Foerster. Here is an educator who not only maintains that professional fields are legitimate candidates for graduate status (if they can define a scholarly as distinct from technical content) but goes further and suggests that pure subject areas give greater attention to professional needs in their graduate programs. This involves the radical assertion that professional fields, no less than subject fields, present problems in research and practice which require high scholarly attainment for solution.

The academic world is organized into a hierarchy in terms of specialization. Status of an individual or a discipline is measured by degree of specialization. In the sense of the material dealt with, librarianship is not a specialization but a generalization. This has been the source of its difficulty in becoming established among academic disciplines. Actually, the most crying need of the academic world, and of the larger world of knowledge, may be synthesis which cuts across specialization-and the librarian may be one of the few agents of synthesis in the realm of scholarship.

Librarianship, then, is not ostracized from the circle of graduate discipline in the view of this book. But neither is it automatically a member of the circle. Like any field, it must present an intellectual content requiring broad scholarly preparation. This view, by clarifying the issue, hastens the day when that intellectual content must be defined. And by its emphasis upon a comprehensive program of graduate study, this view points librarianship toward an orientation for its content that may be summarily suggested in the phrase "the organization of recorded knowledge for use." One cannot help but play with the idea of graduate study in librarianship which would be directed by a university interdepartmental committee having such a title.

Mr. Hollis' call to new roads in graduate education lacks the force and originality to be found in recent calls in undergraduate education by Hutchins, Maritain, Wriston, and others. It does not even present a belated codification of a long-existing trend, as does the $\mathrm{Harvard}$ report. But it is what has been notably lacking in the literature of graduate education, an honest and reflective statement of purpose and method.-Lowell Martin.

\title{
The State University and the Humanities
}

A State University Surveys the Humanities.

Edited with a Foreword by Loren C. Mac-

Kinney, Nicholson B. Adams, and Harry K.

Russell. (University of North Carolina

Sesquicentennial Publications, Louis R.

Wilson, director.) Chapel Hill, University of North Carolina Press, 1945. xi, 262p.

Reading A State University Surveys the Humanities is like strolling down the inviting avenue of an old city, say Boston or Charleston or Williamsburg. Here is an ancient residence, recently renovated; there, one, time- worn and respectably weary but still tenanted; and yonder, across the street, a self-conscious new one, lately erected and bearing, we somehow feel, a shy embarrassment at having been placed in such a sedate and austerely genteel neighborhood.

Our first reaction to this motley is to blame the city fathers for their failure to plan ahead. Are there no zoning regulations here? Unsatisfied, we criticize especially the mayor and his council. Failing there, we naturally find fault with the architects. Then, suddenly, we 
remember that in these days of priorities and shortages one must take what he can get, using unskilled local labor and green lumber, if need be. What matters if this dwelling is carefully planned and livable and that one next door a shotgun structure? The idea is to get the people housed, willy-nilly, even if the planning board has to pull its punches.

The humanist editors of $A$ State University Surveys the Humanities set out "to show that the humanities are not merely a group of academic subjects, but that they represent an ideal which can permeate all human activity." In support of this fact they invited "natural scientists, social scientists, and professional men, as well as men of letters, to collaborate in setting forth past experiences, present problems, and future aspirations in humanistic education." These aims are correctly premised upon a belief in the humanistic ideal (as contrasted with humanistic subjects) which, if properly understood, "involves a broad view of man's struggle to place himself in his environment, and ... offers a noble tradition to guide him in his development." No quarrel is picked with vocational education-man cannot live by bread alone. But necessary though specialized training is, something more is needed, "something that touches the spirit as well as the body, something that exalts the dignity of man's personality." This "something" the humanistic ideal supplies "by emphasizing the development of the whole man, inclusive of special skills, whether mechanical, industrial, artistic, or professional." With so broad a premise, we believe, no thinking man would attempt to disagree. Moreover, its acceptance rightly implies "that educating students into maturity and citizenship in a complex world is a most important obligation of a university."

The humanities as they have been and are taught at the University of North Carolina serve naturally as a point of departure for the seventeen authors whose chapters compose the volume. Except for Wallace E. Caldwell, whose admirable historical section outlines the growth of the humanistic ideal at Chapel Hill, I795-1945, and thereby forms Part I of the volume, each writer was apparently given his head. Part II is the work of eleven in-service instructors (two in literature, and one each in history, philosophy, romance languages, music, art, sociology, edu- cation and psychology, zoology, and mathematics); Part III, the views of four professional men (a doctor, a lawyer, a businessman, and an erstwhile professor of journalism), three of whom are graduates of the university; and Part IV, a concluding essay, by an ex-professor of English, which envisages the future university as one whose whole program is steeped in the humanistic philosophy. Although the majority of contributors come from the ranks of the humanists, the social, biological, and physical sciences, as well as the business world, are adequately represented. It should perhaps be noted that the humanities at Chapel Hill include "the departments of art, classics, comparative linguistics, dramatic art, English, general and comparative literature, Germanic languages, journalism, music, romance languages, and the following departments which also belong to other divisions: education, history, and philosophy."

Throughout the volume there runs the central theme that the division of humanities claims no monopoly on liberal or general education, yet believes that each and every course in the university curriculum should "embody the humanistic spirit and thus inculcate attitudes and habits of approach characteristic of informed and mature persons." Amid the welter of recent books on liberal education this can hardly be called a startling point of view. Hoyt Hudson's Educating Liberally, Jacques Barzun's Teacher in America, the Vanderbilt Conference on the Humanities in Higher Education in the South, Harvard's General Education in a Free Society, and others, such as the Colgate, Princeton, and Yale reports, have within the past few months expressed the same ideas. As Time observed (Dec. ro, 1945, p. 69), "Everybody is doing it." Indeed one may go back at least ninety-two years to read kindred opinions as expressed at the University of Alabama by President Manly and Professor Barnard in the 1850's. ${ }^{1}$ And the close observer will note in Professor Caldwell's introductory survey to $A$ State University that the identical ideas were voiced at Chapel Hill a century or more ago.

Time's tongue-in-cheek observation, quoted above, should not be taken too lightly, it

1 Wills, Elbert V. "Basil Manly, Frederick A. P. Barnard, and the University of Alabama Curriculum Inquiry, 1852-1854." The Southern Association Quarterly 9: 306-I I, August 1945. 
seems. With fidgetiness amounting almost to professional neurosis, humanists throughout the nation have recently arisen to a man to defend the "liberal" arts, "general" education, or the humanistic "spirit." Not one, so far as our perusals have led us, has done much more than run around in a circle, packing the good but dull earth. These sorghum-mill tactics doubtless accomplish an end; but is it the desired end? Even the definitions of the humanities are ofttimes vague, nebulous, or meaningless. For example, that the humanistic ideal is "something that touches the spirit as well as the body, something that exalts the dignity of man's personality" loses some force when we pause to consider that these "somethings" might conceivably be taken as a text by any educator, even a hidebound vocationalist. Perhaps the time is not yet right or perhaps humanists have not yet arrived at a suitable understanding, but the day must soon come when advocates of humanistic learning will be forced to abandon platitudes and get down concretely to an exact analysis of what they have to offer man in his search for worthy citizenship and happy maturity. Or else be hopelessly cornered.

If the theme of $A$ State University is, therefore, old and respectable and, perchance, somewhat recently renovated, the significance of the volume must lie in its unique approach. Other books on the humanities which we have recently examined are written either by single authors or issued jointly by committees; this one differs in that it is built chapter on chapter by individual writers, each of whom cuts his own pattern from the same bolt of cloth.

But $A$ State University has, in our opinion, another requisite of uniqueness. The editors have literally outdone themselves in the selection of contributors from fields other than the humanities. Had the volume been issued in yesteryears, when such humanistic scholars as Greenlaw, Royster, Hibbard, Jones, Weaver, and others of their ilk could have represented the humanities at Chapel Hill, the story might have been different. As the book stands, however, by far the best expressions of the efficacy of liberal education are not voiced by all the fraters in facultate. Rather, the case must rest on the contributions of only one or two of them, a couple of scientists, the businessmen, and two professors who quit the university some fifteen or twenty years ago. Certainly, the cause of the liberal arts will be little helped by $\mathrm{Paul}$ Green's dramatically self-conscious and academic essay entitled "The Creative in Man" or by the sophomoric patchwork of quotations by George C. Taylor called "The Beast in Man." Nor, except negatively, perhaps, will the wordy and time-worn contributions of Howard W. Odum and Archibald Henderson -on "The Social Sciences" and "Mathematics and the Physical Sciences"-aid in fostering the humanistic ideal. On the contrary, it would be difficult to spot a better summary of the role sciences may play in humanistic education than that of Robert $E$. Coker, a zoologist. And, in our opinion, one would look long before finding a neater exposition of the influence of the humanities on the common man now and in the future than that contained in the chapters by Gerald W. Johnson and Norman Foerster. Somewhere between these two extremes lies the undistinguished and ineffectual level of $A$ State $U n i-$ versity.

As we have said, from a distance the avenue is inviting, but the city fathers could have improved the neighborhood noticeably by careful planning and the employment of more experienced architects.

A State University is the first of seventeen books to be issued as the University of North Carolina Sesquicentennial Publications. Inasmuch as the series will cover virtually every phase of the activities of one of the nation's oldest and best-known state universities, the volumes will doubtless be eagerly awaited.W. Stanley Hoole. 